\title{
Crescimento e estagnação: os limites da política econômica brasileira do século XXI
}

\author{
Growth and Stagnation: The Limits of Brazilian Economic Policy in $21^{S T}$ Century
}

Leonardo Flauzino de Souza ${ }^{1}$

\begin{abstract}
Resumo: A economia brasileira vivenciou um ciclo expansivo ao longo da década de 2000, marcado pela expansão do investimento, geração de empregos e aumento da renda corrente. Após a crise econômica de 2008, que, apesar de ter seu epicentro nos mercados de dívida hipotecária norte-americana, se alastrou para várias economias do mundo, a economia brasileira entrou em uma fase de baixo crescimento, queda dos investimentos, mas com manutenção do nível de emprego. Este trabalho tem por objetivo mostrar que o recente ciclo da economia brasileira está intimamente relacionado aos mercados externos, tanto na sua fase expansiva, quanto na recessiva. Os elevados saldos em transações correntes diminuíram a dependência em relação ao capital externo para manter a estabilidade de preços, o que permitiu reduzir a taxa de juros e desvencilhar o investimento agregado. O próprio aumento da renda interna contribuiu para a redução do saldo comercial, mas a crise de 2008 intensificou este movimento, reduzindo as taxas de crescimento da economia nacional. Desta forma, a economia brasileira voltou a depender da entrada de capitais para a manutenção da estabilidade de preços e do arcabouço de políticas macroeconômicas que favorecem este movimento, a sacrificar ainda mais o crescimento do produto.
\end{abstract}

Palavras-chave: Economia Brasileira; Política Macroeconômica; Ciclo Econômico.

Abstract: The Brazilian economy experienced an expansive cycle along the 2000s, marked by the increase of investment, job creation and current income. After the 2008 economic crisis, despite its epicenter in the US mortgage debt markets, its spread to several economies in the world, the Brazilian economy entered a phase of low growth, falling investment, but with maintenance level of employment. This work aims to show that the recent Brazilian economy cycle is closely related to foreign markets, both in its expansion phase, as the recessive. The high current account balances decreased dependence on external capital to maintain price stability, which reduced the interest rate and increased aggregate investment. The increase in domestic income contributed to the reduction in the trade balance, but the 2008 crisis intensified this movement, reducing the growth rates of the national economy. Thus, the Brazilian economy returned to rely on capital inflows to maintain price stability and on macroeconomic policy framework that favor this movement, further sacrificing output growth.

Key words: Brazilian Economy; Macroeconomic policy; Economic Cycle.

JEL: E12; F32; F43.

\section{INTRODUÇÃO}

Após 1994, com o advento do Plano Real, o Brasil alcançou uma relativa estabilidade de preços ao adotar um regime macroeconômico de metas cambiais $^{2}$, o qual consistia em manter a taxa de câmbio relativamente estável, permitindo sua flutuação dentro de patamares previamente estabelecidos. Pelo lado fiscal, para Bacha (1994), o sucesso do regime estava atrelado à

\footnotetext{
${ }^{1}$ Economista. Doutorando pela Universidade Estadual de Campinas. Professor da Universidade Federal de Mato Grosso

2 Ver Modenesi (2005).
} 
resolução do déficit público potencial ${ }^{3}$, para o qual era necessário reduzir substancialmente os gastos públicos ou elevar a tributação.

No entanto, a manutenção da paridade cambial em dado patamar que não causasse o recrudescimento da inflação levava a déficits correntes persistentes no balanço de pagamentos. As massivas entradas de capitais atraídos pelas altas taxas de juros de curto prazo dos títulos da dívida pública brasileira financiavam os déficits correntes. $\mathrm{Em}$ síntese, o regime macroeconômico brasileiro do fim do século XX estava atrelado à taxa de câmbio administrada, contração fiscal e retração monetária como medidas para manter a estabilidade de preços recém-alcançada.

O referido contexto histórico-institucional remete às abordagens teóricas de Triffin (1960), que afirmou ser impossível conciliar um regime de câmbio fixo (ou administrado) com mobilidade de capital e autonomia da política monetária ${ }^{4}$. Em outras palavras, para obter a estabilidade inflacionária era supostamente necessário ancorar os preços internos aos externos através de uma taxa de câmbio administrada em um patamar baixo (em reais por dólares), ou seja, manter a sobrevalorização da moeda doméstica, o que implicava em elevados déficits correntes financiados pelos movimentos de capitais a sacrifício da autonomia da política monetária. Assim, as taxas de juros internas variariam ao sabor das taxas externas ponderadas por um duplo risco de default: a capacidade do Governo em honrar suas dívidas e do Banco Central em manter a taxa de câmbio estável. Tais características criavam um incentivo adicional à contração fiscal e monetária.

Em um cenário de contração da liquidez internacional estimulado pelas crises da Ásia em 1997 e da Rússia em 1998, exacerbação de um movimento fly to quality e as saídas de capital, essencialmente de curto prazo, a manutenção da âncora cambial se tornou infactível. Assim, em 1999, o regime macroeconômico em questão ruiu e foi substituído pelo regime de metas de inflação com câmbio flutuante e metas de superávit primário.

Segundo Carneiro (2003), a passagem para um regime com taxas de câmbio flutuante permitiria, segundo o modelo canônico ${ }^{5}$, a retomada da autonomia da política monetária. Entretanto, para o autor, as características específicas da economia brasileira não permitem inferir que a retomada da autonomia da política monetária passaria, exclusivamente, pela presença de um regime de câmbio flutuante, sendo necessária a adoção de outras políticas, como a de controle de capitais ${ }^{6}$.

\footnotetext{
3 Segundo Bacha (1994), o país sofria do "Efeito Tanzi às Avessas", na qual o déficit fiscal do governo é massivamente financiado pelo imposto inflacionário, uma vez que a arrecadação de impostos está indexada à inflação e as despesas públicas não, o contrário do "Efeito Oliveira-Tanzi" tradicional. Desta forma, uma redução abrupta da inflação realizaria o até então déficit fiscal potencial, levando a uma forte expansão monetária e retomada da inflação.

4 O referido trilema ou trindade impossível é alvo de estudos de Eichengreen (1996), Serrano (2002) e Obstfeld, Shambaugh \& Taylor (2004).

5 Por modelo canônico entenda-se o modelo desenvolvido por Mundell (1963) e Fleming (1962). É importante ressaltar que os condicionantes desenvolvidos por Triffin (1960) em seu trilema estão em consonância com o modelo em questão.

6 É importante ressalvar que Mundell (1963) afirmou que suas "conclusões eram mais preto e branco do que tons de cinza" (p. 485, tradução própria) e que a validade do modelo estava relacionada ao cumprimento hipóteses fortes como perfeita substitutibilidade entre os ativos do sistema e a inexistência e movimentos especulativos e mercados futuros. Nenhuma destas condições pode ser observada na realidade.
} 
Os dados apresentados pela Tabela 1 ilustram o comportamento supracitado. Os superávits primários (exceto 1997) evidenciam o esforço de contração fiscal por parte do governo, no entanto, a Estado não deixou de expandir liquidez pública pela via do endividamento, como mostram os déficits nominais ${ }^{7}$. As taxas de juros fortemente elevadas no período mostram 0 tamanho da contração monetária necessária para atrair capitais externos capazes de financiar o déficit em transações correntes, crescente de 1994 a 1998. Entretanto, esta medida não foi suficiente. A partir de 1997, com a crise internacional da Ásia e o efeito contágio nos mercados emergentes ${ }^{8}$, a contração da liquidez internacional obrigou o país a elevar seu nível de endividamento externo. Em 1999, este processo se mostrou insustentável e o regime cambial vigente foi substituído.

O objetivo deste artigo é analisar o comportamento da economia brasileira neste início de século XXI e explicitar as implicações sobre regime macroeconômico adotado pós-crise cambial de 1999. Para tal, este trabalho será dividido em duas seções. A primeira dedicada à exposição do cenário macroeconômico do Brasil recente e uma análise do comportamento da economia nos últimos anos. A segunda seção evidenciará como os objetivos das políticas econômicas interagiram com as modificações da economia brasileira na última década.

\section{O CENÁRIO ECONÔMICO DOS ANOS 2000}

Após a crise de balanço de pagamentos de 1998 e a incapacidade do Banco Central brasileiro em manter a taxa de câmbio dentro dos patamares determinados, abandonou-se o regime de metas cambiais e passou-se a adotar um regime de metas de inflação supostamente ancorado pelo superávit primário (ou estabilidade do déficit nominal) e taxa de câmbio flutuante, formando assim o tripé de política macroeconômica.

O regime macroeconômico iniciado em 1994 e encerrado em 1998 tinha por objetivo a manutenção da inflação em níveis baixos e estáveis através da ancoragem dos preços domésticos aos preços externos e manutenção da taxa de câmbio estável. Esta ancoragem só foi possível de ser realizada com a abertura comercial e financeira promovida no inicio da década de 1990, que permitiu maiores fluxos de importações e entradas massivas de capitais.

\footnotetext{
7 Segundo Godley (1999), o processo oposto ao mencionado, retração da liquidez pública ou superávit nominal, se caracteriza como um processo insustentável ao longo do tempo, uma vez que os déficits nominais se transformam em ganhos privados. Para o autor, analisando séries históricas para a economia dos EUA, os superávits nominais públicos apenas foram obtidos em momentos em que o setor privado se tornou amplamente deficitário devido a um processo crônico de endividamento.

${ }^{8}$ Ver Farhi (2006).
} 
Tabela 1: Síntese das Principais Variáveis Macroeconômicas de 1994 a 1999.

\begin{tabular}{c|ccccccc}
\hline \multirow{2}{*}{ Ano } & $\begin{array}{c}\text { Resultado } \\
\text { Primário por } \\
\text { PIB (\%) }\end{array}$ & $\begin{array}{c}\text { Resultado } \\
\text { Nominal por } \\
\text { PIB }(\%)^{1}\end{array}$ & $\begin{array}{c}\text { Taxa de } \\
\text { Juros } \\
(\%)^{2}\end{array}$ & $\begin{array}{c}\text { Taxa de } \\
\text { Crescimento } \\
\text { do PIB (\%) }\end{array}$ & $\begin{array}{c}\text { Saldo em } \\
\text { Transações } \\
\text { Correntes }^{3}\end{array}$ & $\begin{array}{c}\text { Saldo em } \\
\text { Balanço de } \\
\text { Pagamentos }^{3}\end{array}$ & $\begin{array}{c}\text { Dívida Externa } \\
\text { Líquida do }\end{array}$ \\
\hline 1994 & - & - & 49,9 & 5,33 & $-1.811,23$ & $7.215,20$ & $44.357,26$ \\
1995 & 0,55 & $-1,49$ & 40,3 & 4,42 & $-18.383,71$ & $12.918,90$ & $38.132,35$ \\
1996 & 0,35 & $-1,16$ & 24,9 & 2,15 & $-23.502,08$ & $8.666,10$ & $31.593,17$ \\
1997 & $-0,25$ & $-2,27$ & 40,8 & 3,38 & $-30.452,26$ & $-7.907,16$ & $38.580,30$ \\
1998 & 0,51 & $-4,61$ & 29,0 & 0,04 & $-33.415,90$ & $-7.970,21$ & $57.176,61$ \\
1999 & 2,13 & $-2,47$ & 19,0 & 0,25 & $-25.334,63$ & $-7.822,04$ & $108.768,75$ \\
\hline
\end{tabular}

${ }^{1}$ Governo Central.

2Fim de período.

${ }^{3}$ Em milhões de US dólares.

Fonte: Secretaria do Tesouro Nacional e Banco Central do Brasil.

O regime macroeconômico que deu início em 1999 tinha por objetivo manter a inflação estável através da restrição fiscal e controle da taxa de juros dos títulos da dívida pública de curto prazo associados à SELIC (Sistema Especial de Liquidação e de Custódia). Segundo o modelo mainstream convencional ${ }^{9}$, um aumento na taxa de juros reduziria o nível de atividade e elevaria a taxa de desemprego, o que resultaria na queda da inflação. No entanto, como ressalta Farhi (2006), para o caso brasileiro, a taxa de juros teria sido usada para influenciar o nível de inflação via taxa de câmbio: uma elevação da taxa de juros atrairia mais capitais para o país, reduzindo a taxa de câmbio (em reais por dólares), tornando os preços dos bens importados mais baratos, o que reduziria a inflação.

Tabela 2: Principais Variáveis Macroeconômicas da Política Monetária

\begin{tabular}{c|ccccc}
\hline Ano & $\begin{array}{c}\text { Taxa de } \\
\text { Juros }(\%)^{1}\end{array}$ & $\begin{array}{c}\text { Taxa de } \\
\text { Câmbio } \\
(\mathrm{R} \$ / \mathrm{US} \$)^{1}\end{array}$ & $\begin{array}{c}\text { Inflação } \\
(\%)^{2}\end{array}$ & $\begin{array}{c}\text { Taxa de } \\
\text { Desemprego } \\
(\%)^{3}\end{array}$ & $\begin{array}{c}\text { Taxa de } \\
\text { crescimento } \\
\text { do PIB }(\%)\end{array}$ \\
\hline 2000 & 15,84 & 1,95 & 5,97 & 10,00 & 4,31 \\
2001 & 19,05 & 2,32 & 7,67 & 11,60 & 1,31 \\
2002 & 24,90 & 3,53 & 12,53 & 11,40 & 2,66 \\
2003 & 16,33 & 2,89 & 9,30 & 12,00 & 1,15 \\
2004 & 17,75 & 2,65 & 7,60 & 10,00 & 5,71 \\
2005 & 18,05 & 2,34 & 5,69 & 9,70 & 3,16 \\
2006 & 13,19 & 2,14 & 3,14 & 9,00 & 3,96 \\
2007 & 11,18 & 1,77 & 4,46 & 9,30 & 6,09 \\
2008 & 13,66 & 2,34 & 5,90 & 8,30 & 5,17 \\
2009 & 8,65 & 1,74 & 4,31 & 8,50 & $-0,33$ \\
2010 & 10,67 & 1,67 & 5,91 & 7,40 & 7,53 \\
2011 & 10,91 & 1,88 & 6,50 & 6,90 & 2,73 \\
2012 & 7,29 & 2,04 & 5,84 & 7,60 & 1,03 \\
2013 & 9,90 & 2,34 & 5,91 & 7,50 & 2,49 \\
\hline
\end{tabular}

1Fim de período.

2Índice Nacional de Preços ao Consumidor Amplo (IPCA).

${ }^{3}$ Região metropolitana de São Paulo.

Fonte: IBGE, Banco Central do Brasil, Seade.

${ }^{9}$ Ver Fisher \& Blanchard (1989). 
Como pode ser visto pela Tabela 2, nos anos em que houve elevação da taxa de câmbio, houve também aumento do nível de inflação, com exceção dos anos de 2007, 2010 e 2012, sendo que os dois primeiros apresentam as mais elevadas taxas de crescimento do PIB, inferindo um efeito inflacionário devido a um aquecimento da demanda doméstica. Já 2012 apresenta um crescimento muito baixo, o que refletiu na redução da inflação mesmo com aumento da taxa de câmbio.

Também é possível inferir, pela tabela anterior, que as elevações na taxa de câmbio são acompanhadas por elevações na taxa de juros, com exceção dos anos 2004, 2005, 2010 e 2012. Nos dois primeiro anos mencionados, a inflação ainda se apresentava em níveis elevados devido ao choque cambial de 2002. O ano de 2010 apresentou uma taxa de juros maior em resposta à maior inflação promovida pelo crescimento. Já o ano de 2012 caracterizou-se por menores taxas de juros na tentativa de reerguer 0 crescimento. Ao longo da década, nota-se que o crescimento do PIB mostrouse errático. No entanto, a trajetória de queda da taxa de juros acompanha uma trajetória de elevação do produto.

É possível observar pela Tabela 2 que de 2002 a 2007 a taxa de juros inicia uma trajetória de queda com índices de inflação estáveis e declinantes. Isto ocorreu devido ao aumento do saldo exportador e surgimento de superávits em transações correntes no período (ver Gráfico 1). Os saldos em transações correntes possibilitaram a entrada de moeda estrangeira no país pela via comercial, dependendo menos das elevadas taxas de juros na tentativa de atrair capitais, valorizar a moeda doméstica e reduzir a inflação.

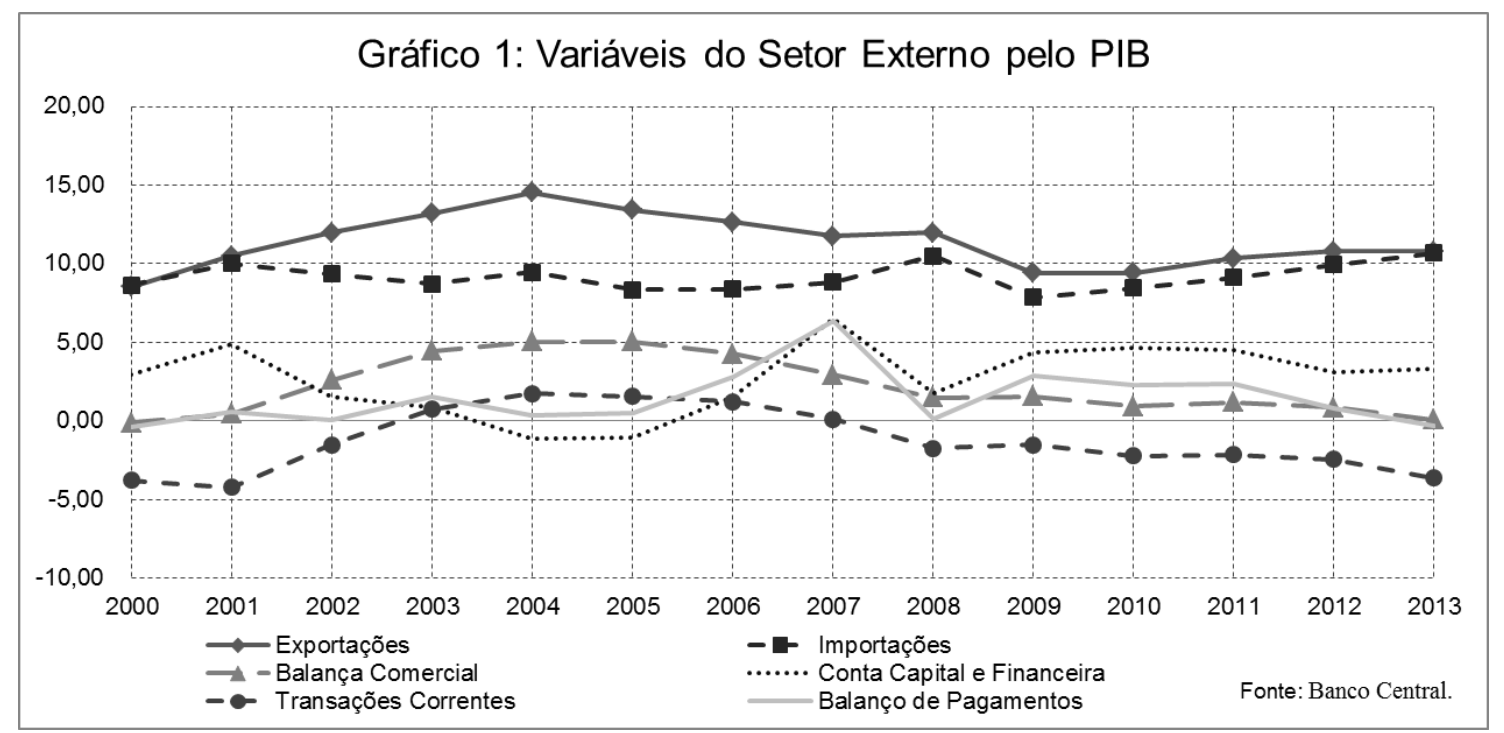

Fonte: Banco Central

Neste mesmo período a conta capital e financeira mostra uma trajetória declinante em razão da queda da taxa de juros brasileira em contraposição com a elevação da taxa de juros nos mercados de dívidas internacionais, em 
especial nos mercados norte-americanos ${ }^{10}$. Este cenário foi possibilitado pela forte expansão das exportações, alavancadas inicialmente com o choque cambial de 2002, como pode ser visto pela Tabela 2, e posteriormente pela elevação dos preços das commodities nos mercados internacionais, como demonstrado pelo Gráfico 2:

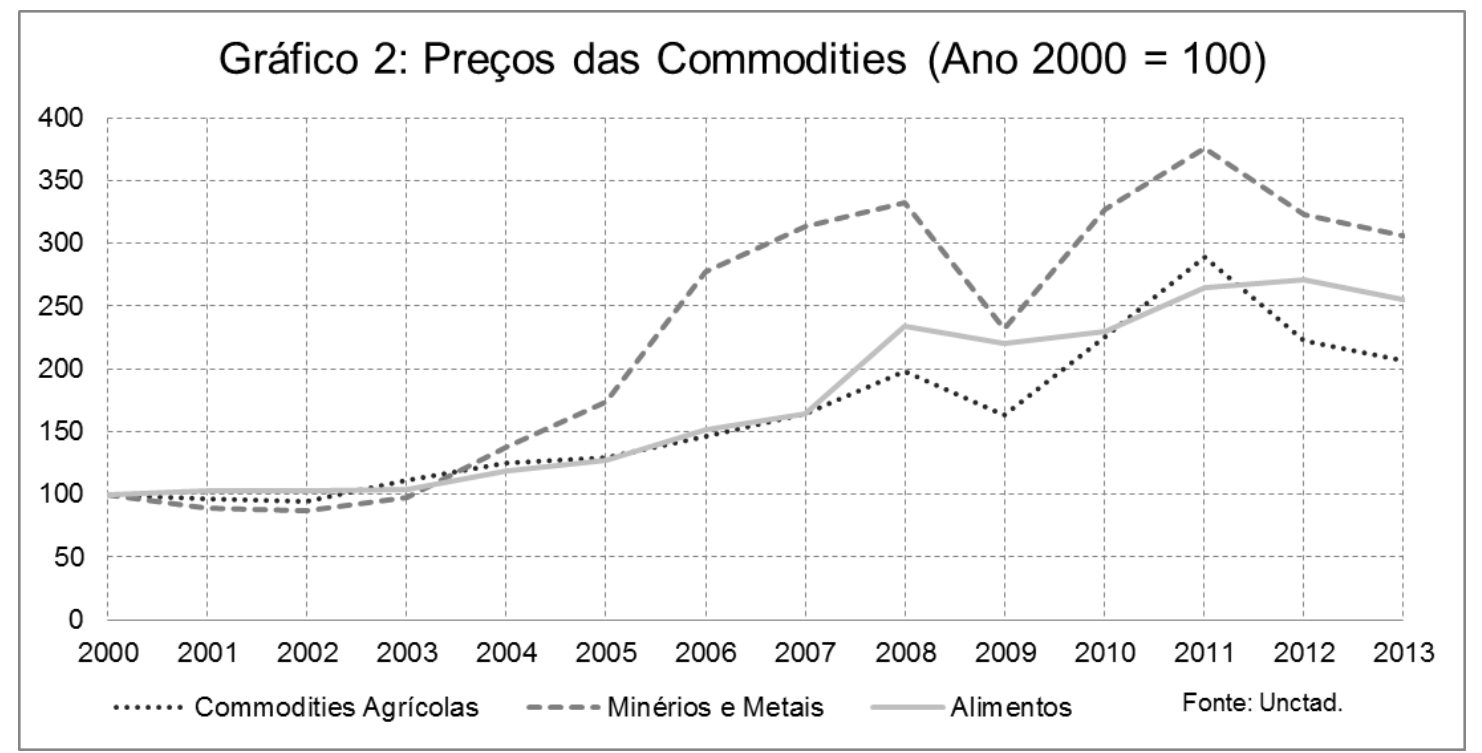

Fonte: Unctad

Desta forma, o boom nos preços internacionais das commodities, em especial os agrícolas, ampliou os saldos comerciais, antes praticamente inexistentes, e possibilitou o surgimento de saldos em transações correntes positivos, acarretando na entrada de moeda externa pela via transacional e reduzindo a dependência da entrada de capitais pela via financeira.

Segundo Wray (2008), o movimento de elevação dos preços de commodities não esteve apenas relacionado à elevação da demanda mundial oriunda do elevado crescimento de outros países emergentes como China e Índia. O autor não negligencia a importância destes fatores, mas elenca também a atuação dos investidores institucionais nestes mercados. Esses investidores atuam como captadores de liquidez e tomam decisões de aplicação de capital em prazos mais curtos visando à obtenção de retornos pecuniários associados às oscilações dos preços de ativos líquidos ou de seus preços diferidos nos mercados subjacentes (derivativos financeiros).

Portanto, a atuação destes investidores nos mercados de commodities contribuiu para elevar os preços destes ativos, uma vez que o contexto de elevação da demanda por tais bens criava expectativas de preços ascendentes. Ou seja, os investidores institucionais teriam uma atuação prócíclica, contribuindo para elevar de forma drástica os preços destes ativos em momentos de expectativas de preços futuros mais elevados e para baixar de forma igualmente intensa estes preços quando as expectativas se revertiam. A queda nos mercados de commodities também engendraria impactos relevantes:

10 Ver Souza (2012). 
"Falling commodity prices will generate problems; production decisions as well as portfolio allocations have been made on the expectation of rising prices. A lot of leveraged money has gone into commodity markets (including physicals as well as futures), so just as falling real estate prices are devastating for households, for the real estate sector generally, and for financial markets, there will be significant fallout from the slump in commodity prices." (Wray, 2008, p. 10).

O impacto na queda dos mercados de commodities não se traduzirá apenas como receitas menores aos produtores destas, mas na possibilidade de que estes sejam incapazes de honrar as dívidas contratadas para financiar sua produção, gerando impactos produtivos que podem ser amplificados pelas alterações no balanço de pagamentos e na taxa de câmbio para o caso brasileiro.

A elevada liquidez nos mercados de dívidas norte-americanos e a busca por retornos pecuniários em um cenário de elevação dos custos de captação (elevação das taxas de juros nos EUA), como ressaltado por Wray (2008), contribuíram para o aumento dos preços das commodities. Vale ressaltar que a importância do aumento da demanda gerada pelo crescimento de mercados emergentes como China e Índia não deve ser negligenciada.

O impacto mais imediato deste cenário internacional foi o aumento dos saldos externos da economia brasileira, tornando-a menos depende da necessidade de captação de recursos pela via financeira na tentativa de atrair capitais, valorizar a moeda doméstica, reduzir a taxa de câmbio e, assim, manter estável a inflação. Logo, a bonança da liquidez externa criou espaço para a redução da taxa de juros interna, uma vez que reduziu a dependência de financiamento externo.

A redução das taxas de juros criou a possibilidade de se alavancar 0 crescimento da economia brasileira pelo aumento do investimento, de tal forma que a redução das exportações em relação ao PIB (observada pelo Gráfico 1), a partir de 2004, é consequência da forte expansão do PIB e redução da taxa de câmbio e não de uma redução das exportações. Com a crise de 2008 e a inflexão nos mercados de commodities esta situação se reverte, apesar da ligeira recuperação de 2011, iniciando a etapa de estagnação da economia brasileira.

Ao observar os dados apresentados pela Tabela 3, pode-se inferir que em praticamente todos os anos nos quais o PIB apresentou aumento na sua trajetória de crescimento, a participação do investimento no produto também aumentou, com a exceção de 2002 e 2008. O ano de 2002 apresentou um aumento no crescimento do PIB em relação ao ano anterior (Tabela 2), mas com redução da participação do investimento, isto em razão do choque cambial que desestimulou importações e ampliou exportações. Neste caso, o saldo exportador contribuiu para o aumento do crescimento, mesmo com a queda da participação do investimento.

O ano de 2008 apresentou uma situação contrária: queda do crescimento em relação ao ano anterior com aumento da participação do investimento. Porém, este ano marcou o inicio da crise internacional que teve impactos produtivos globais altamente relevantes. É possível observar, pela análise da Tabela 3 , que em 2008, a variação positiva dos estoques foi 
expressiva, ou seja, os investimentos realizados - produção de máquinas, equipamentos, construção de infraestrutura em geral e outros - não foram vendidos, contribuindo para um nível de crescimento menor neste ano em relação ao anterior.

Tabela 3: Participação do Investimento no PIB e Composição do Investimento de 2000 a 2013

\begin{tabular}{c|c|cc|ccc}
\hline \multirow{2}{*}{ Ano } & Participação do & \multicolumn{3}{|c|}{ Investimento } & \multicolumn{3}{c}{ Formação Bruta de Capital Fixo } \\
\cline { 3 - 7 } & $\begin{array}{c}\text { Investimento no } \\
\text { PIB (\%) }\end{array}$ & $\begin{array}{c}\text { Variação dos } \\
\text { Estoques (\%) }\end{array}$ & $\begin{array}{c}\text { Formação Bruta } \\
\text { de Capital Fixo (\%) }\end{array}$ & $\begin{array}{c}\text { Construção } \\
(\%)\end{array}$ & $\begin{array}{c}\text { Máquinas e } \\
\text { Equipamentos (\%) }\end{array}$ & $\begin{array}{c}\text { Outros } \\
(\%)\end{array}$ \\
\hline 2000 & 18,3 & 7,95 & 92,1 & 49,6 & 42,7 & 7,67 \\
2001 & 18,0 & 5,53 & 94,5 & 46,5 & 45,8 & 7,68 \\
2002 & 16,2 & $-1,17$ & 101,2 & 47,3 & 44,3 & 8,39 \\
2003 & 15,8 & 3,13 & 96,9 & 44,2 & 46,8 & 9,01 \\
2004 & 17,1 & 5,96 & 94,0 & 43,7 & 47,9 & 8,37 \\
2005 & 16,2 & 1,65 & 98,4 & 42,3 & 49,9 & 7,85 \\
2006 & 16,8 & 1,94 & 98,1 & 40,4 & 51,6 & 7,93 \\
2007 & 18,3 & 4,84 & 95,2 & 38,3 & 54,1 & 7,58 \\
2008 & 20,7 & 7,64 & 92,4 & 36,3 & 56,7 & 7,00 \\
2009 & 17,8 & $-1,29$ & 101,3 & 42,3 & 50,1 & 7,59 \\
2010 & 20,2 & 3,84 & 96,2 & 40,6 & 52,5 & 6,89 \\
2011 & 19,7 & 2,27 & 97,7 & 41,4 & 52,4 & 6,24 \\
2012 & 17,5 & $-3,71$ & 103,8 & 43,8 & 49,7 & 6,52 \\
2013 & 17,9 & $-1,62$ & 101,6 & 41,8 & 51,8 & 6,39 \\
\hline
\end{tabular}

Fonte: ipeadata

Para Keynes (1936) e Kalecki (1977), a variação dos estoques é uma variável relevante para se compreender a dinâmica do investimento no curto prazo, sendo que aumentos expressivos nos estoques em um determinado período tenderiam a comprometer o crescimento do investimento nos períodos subsequentes. Nota-se que, pela Tabela 2 e Tabela 3, de 2000 a 2003 e após 2008, o PIB apresentou taxas de crescimento erráticas acompanhadas de uma trajetória de queda da participação do investimento no PIB e de um movimento de variação dos estoques de bens de capital também errático.

De 2004 a 2008, o crescimento do PIB permaneceu em patamares mais elevados, com elevação da participação do investimento no produto e variação dos estoques positivas e estáveis. Os anos nos quais a variação dos estoques é negativa sinalizam que alguns dos investimentos realizados no ano não foram feitos com a produção de novos bens de capital, mas pela venda de bens já produzidos. Este cenário pode sinalizar que o setor produtor de bens de capital não projeta retornos futuros satisfatórios a ponto de ampliar seus investimentos, o que pode incorrer em impactos significativos para 0 crescimento do produto ao longo dos anos.

A crise de balanço de pagamentos brasileira em 1999, acompanhada das crises dos países asiáticos no fim da década de 1990 e da crise bursátil das empresas de tecnologia da informação e comunicação nos EUA em 2000 e a crise da Argentina em 2001, criou, seguindo o raciocínio de Keynes (1936), um estado de expectativas de longo prazo extremamente negativo, o que foi responsável por encurtar os prazos de decisões do setor produtivo, engendrando movimentos erráticos no investimento e no produto. De 2004 a 2008, em um cenário externo positivo de crescimento e expansão da liquidez, 
com taxas de juros internas em trajetória declinante e inflação estável, criou-se um ambiente propício para alongamento de prazos com expectativas de expansão prolongadas e uma trajetória de expansão de investimentos e do produto.

Neste aspecto, 2008 se apresenta como um turning point de grande relevância. Em um primeiro aspecto, a inversão dos mercados de commodities, redução da participação das exportações no PIB e aumento da participação das importações, engendrando saldos em transações correntes novamente negativos, contribuíram para a interrupção da trajetória de queda da taxa de juros. Os efeitos cambiais foram imediatos, criando uma trajetória de aumento da taxa de câmbio e desvalorização da moeda doméstica, o que acarretou no aumento dos patamares de inflação (Tabela 2).

Em segundo lugar, com expectativas de longo prazo corroídas, a lógica de curto prazo se sobrepõe, tornando a administração dos estoques de bens de capital novamente relevante e errática. O baixo crescimento recente vem acompanhado de uma queda da participação do investimento e das vendas de estoques de bens de capital (variação negativa dos estoques na Tabela 3) consolidados nos períodos anteriores (variação positiva dos estoques na Tabela 3).

Como ressaltaram Keynes (1930) e Minsky (1975), a decisão de investir precisa ser validada pelo sistema bancário através do fornecimento de crédito. Neste aspecto, como demostraram Dedecca, Trovão \& Souza (2014), os períodos de aumento do investimento também foram caracterizados por elevação na relação entre crédito e PIB, em especial pelo aumento da participação do Banco Nacional do Desenvolvimento Econômico e Social (BNDES). O BNDES teve um aspecto crucial no financiamento do investimento ao fornecer crédito a taxas de juros subsidiadas.

Stiglitz \& Greenwald (2004) demonstram que em mercados com elevadas taxas de juros e demanda por crédito pode-se consolidar uma situação de racionamento de crédito. Nesta situação, infere-se que uma política de fornecimento de crédito subsidiado pode contribuir para a redução do racionamento de financiamento. As taxas de juros brasileiras estão entre as mais elevadas do mundo e, ao se comparar os resultados apresentados por Dedecca, Trovão \& Souza (2014) para o crédito da economia brasileira com os dados construídos por Dembiermont, Drehmann \& Muksakunratana (2013) para o crédito na economia mundial, pode-se observar que a relação entre crédito e PIB do Brasil esteve em valores baixos para os padrões internacionais, aproximando-se de valores apresentados pela Índia ou México, mas muito distantes da China e outros países asiáticos, bem como das economias desenvolvidas. Estes fatores podem atuar como uma sinalização de racionamento de crédito, no qual o setor bancário demanda retornos demasiadamente elevados, estimulados pelas altas taxas da dívida pública, expulsando do mercado projetos de investimento viáveis, mas com taxas de retornos abaixo da taxa de juros dos empréstimos.

As questões patrimoniais assumem importância preponderante após a crise de 2008, uma vez que os investimentos foram financiados com expectativas de longo prazo de crescimento elevado, o que acarreta na possibilidade de incapacidade das empresas em honrarem suas dívidas. Segundo Rocca \& Santos Júnior (2014), houve uma acentuada na redução nos 
lucros líquidos das empresas após 2008, apesar da recuperação de 2010, diminuindo a liquidez das empresas, mas ainda a manter sua solvência.

A redução dos lucros vem acompanhada da redução da participação do investimento e redução dos estoques de bens de capital (Tabela 3). Uma vez que, como sinalizam Rocca \& Santos Júnior (2014), quase $50 \%$ do investimento é financiado com lucros retidos, a redução destes também contribuiu para a redução da participação dos investimentos no PIB. Este movimento já havia sido sinalizado por Kalecki (1977) e Steindl (1983): a redução dos investimentos vem acompanhada de queda de lucros, dificuldade em honrar dívidas contratadas nas etapas de execução dos projetos de ampliação da capacidade produtiva e incapacidade de retomar o crescimento econômico.

Pela análise da Tabela 3, ao longo da década, os investimentos em máquinas e equipamentos se sobressaem aos investimentos em construção, tornando-se parte mais relevante da composição da formação bruta de capital fixo. Se o ciclo recente encontrou seus limites de expansão, o setor de construção poderia assumir maior preponderância, principalmente através de obras de infraestrutura, como sinaliza IMF (2014). Este aponta para a necessidade de reutilizar a política fiscal no financiamento de novas obras de infraestrutura na tentativa de recompor a demanda global, uma vez que há evidências de que a política monetária via redução da taxa de juros pode ter se tornado incapaz de recompor a demanda privada pelo aumento de endividamento ${ }^{11}$.

A dinâmica supracitada (saldos em transações correntes que permitiram a redução da inflação via redução da taxa de câmbio de forma mais estável e tornaram factível a redução da taxa de juros e desvencilhamento do investimento privado) impactou, também, nas contas públicas.

Como já havia ressaltado Kalecki (1977), saldos externos contribuem para a geração de poupanças internas públicas e privadas. Em outras palavras, os ganhos com as transações correntes se transformaram, em elevação de lucros para o setor privado e em aumento da arrecadação para o setor público. Desta forma, nota-se através da observação da Tabela 4 o aumento do superávit primário de 2002 a 2008, ficando sempre acima dos $2 \%$. Como mencionado anteriormente, em 2002, inicia-se a recuperação da balança comercial devido à forte desvalorização da moeda doméstica (Tabela 2 e Gráfico 1); de 2004 a 2008, apesar da valorização da moeda interna, a expansão do preço das commodities contribui para a geração de saldos externos (Gráficos 1 e 2); após 2008, a crise internacional reverte este quadro e as finanças públicas também ficaram comprometidas. O Gráfico 1 demonstra que em 2004 e 2006 o país obteve os maiores saldos externos; nestes anos o governo também obteve os maiores superávits primários, como pode ser visto pela Tabela 4.

\footnotetext{
${ }^{11}$ A armadilha da liquidez pode ser caracterizada como a incapacidade de reduções na taxa de juros em elevar o nível de gasto e, consequentemente, a renda agregada. A formulação original de Keynes (1936) envolve uma situação limite na qual os agentes preferem reter a moeda incondicionalmente a gastá-la ou emprestá-la. O atual arcabouço não se trata desta situação limite, mas de um processo de desendividamento. As reduções na taxa de juros não irão elevar o nível de gasto, uma vez que este gasto é financiado pela tomada de empréstimos, e agentes altamente endividados não irão tomar novos empréstimos mesmo a taxas de juros mais baixas devido a suas dificuldades correntes em honrar as dívidas previamente contratadas.
} 
Tabela 4: Resultados do Governo em relação ao PIB (\%)

\begin{tabular}{c|ccc|ccc}
\hline Ano & $\begin{array}{c}\text { Resultado } \\
\text { Primário }^{1}\end{array}$ & $\begin{array}{c}\text { Juros } \\
\text { Nominais }\end{array}$ & $\begin{array}{c}\text { Resultado } \\
\text { Nominal }^{1}\end{array}$ & $\begin{array}{c}\text { Dívida } \\
\text { Total } \\
\text { Líquida }^{2}\end{array}$ & $\begin{array}{c}\text { Dívida } \\
\text { Externa } \\
\text { Líquida }^{2}\end{array}$ & $\begin{array}{c}\text { Dívida } \\
\text { Interna } \\
\text { Líquida }^{2}\end{array}$ \\
\hline 2000 & 1,73 & $-3,85$ & $-2,12$ & 47,7 & 9,44 & 38,3 \\
2001 & 1,69 & $-3,63$ & $-1,94$ & 52,0 & 9,61 & 42,4 \\
2002 & 2,16 & $-2,84$ & $-0,68$ & 60,4 & 15,7 & 44,7 \\
2003 & 2,28 & $-5,94$ & $-3,66$ & 54,8 & 11,2 & 43,7 \\
2004 & 2,70 & $-4,09$ & $-1,39$ & 50,6 & 7,89 & 42,7 \\
2005 & 2,60 & $-6,01$ & $-3,41$ & 48,4 & 3,16 & 45,3 \\
2006 & 2,17 & $-5,31$ & $-3,14$ & 47,3 & $-1,17$ & 48,4 \\
2007 & 2,23 & $-4,47$ & $-2,24$ & 45,5 & $-7,45$ & 53,0 \\
2008 & 2,35 & $-3,17$ & $-0,82$ & 38,5 & $-11,0$ & 49,5 \\
2009 & 1,31 & $-4,62$ & $-3,31$ & 42,1 & $-9,03$ & 51,1 \\
2010 & 2,09 & $-3,30$ & $-1,21$ & 39,1 & $-9,54$ & 48,7 \\
2011 & 2,25 & $-4,36$ & $-2,11$ & 36,4 & $-13,0$ & 49,4 \\
2012 & 1,96 & $-3,35$ & $-1,39$ & 35,3 & $-14,1$ & 49,4 \\
2013 & 1,55 & $-3,84$ & $-2,28$ & 33,6 & $-14,8$ & 48,3 \\
\hline
\end{tabular}

${ }^{1}$ Governo Central.

2Setor Público.

Fonte: Secretaria do Tesouro Nacional e Banco Central do Brasil

Segundo Lopreato (2006), a busca pelo superávit primário tem a função de ancorar a política monetária ao criar parâmetros para a estabilidade da dívida e compromisso com o pagamento da mesma, contribuindo para a manutenção da estabilidade das expectativas quanto ao risco de default da dívida pública. Ao criar um ambiente de expectativas favoráveis ao investidor estrangeiro interessado em adquirir títulos da dívida pública, a atração de capitais internacionais seria facilitada mesmo a uma taxa de juros menor. A entrada de tais recursos contribuiria para a queda da taxa de câmbio e redução da inflação. Entretanto, a existência de déficits nominais significativos é responsável pelo aumento do endividamento interno (Tabela 4), o que poderia sugerir ao investidor internacional que risco de default estaria a aumentar. Logo, a suposta ancoragem proposta por Lopreato (2006) dependeria de certa miopia dos investidores domésticos e externos.

$\mathrm{Na}$ verdade, a combinação de superávit primário e déficit nominal cria uma situação singular, na qual a liquidez criada pelo Estado é captada por agentes privados específicos: os detentores da dívida pública. Como identificou Lerner (1943), a expansão monetária promovida pelo gasto fiscal se transforma em poder de gasto de agentes privados, o qual, uma vez efetivado, contribui para o aumento de preços. Desta forma, do ponto de vista dos fluxos monetários, uma política fiscal contracionista, representada pela meta de superávit primário, contribui para reduzir o poder de gasto de agentes privados, criando uma pressão para a baixa de preços nos mercados de bens. Por outro lado, pela via dos estoques de riqueza, a liquidez pública continua se expandindo através do déficit nominal e aumento da dívida interna, a qual é 
captada por agentes privados sem passar pelo mercado de bens e inflar seus preços.

Em momentos de instabilidade doméstica ou internacional, os agentes nacionais e internacionais realizam a liquidação destes títulos (ou parte deles) e buscam salvaguarda em ativos externos, uma vez que os ativos internos não são vistos como ativos de reserva, mas sim ativos de investimento ou especulação $^{12}$. Na tentativa de conter o depauperamento do balanço de pagamentos, a elevação da taxa de câmbio e seu corolário mais imediato, o aceleramento inflacionário, a autoridade monetária é obrigada a elevar a taxa de juros de referência, oferecendo retornos mais atrativos para compensar a percepção negativa acerca da liquidez dos ativos domésticos.

Como ressalta Dos Santos \& Macedo e Silva (2010), da mesma forma que os saldos externos são responsáveis por ampliar as poupanças pública e privada - movimento observado entre 2003 e 2007 para a economia brasileira - o déficit público é adquirido por agentes privados internos ou externos movimento perene na economia nacional, como supracitado - e os resultados privados negativos são adquiridos pelo Estado ou pelo setor externo - um possível cenário após a crise de 2008. Qualquer um destes processos (saldos externos, déficit público ou prejuízos privados) terá como corolário o aumento do endividamento dos agentes associados a cada um destes setores ${ }^{13}$.

Desta forma, no período de elevado crescimento, de 2004 a 2008, notase a presença de amplos saldos comerciais, sendo que o saldo em transações correntes se manteve superavitário de 2003 a 2007. No mesmo período a dívida pública interna se expandiu significativamente com elevados déficits nominais. Estes fenômenos implicam nos aumentos dos ganhos privados, 0 que contribuiu para ampliar o investimento, notadamente superior no período.

Este mesmo cenário permitiu o desendividamento externo do setor público, como pode ser visto pela Tabela 4. As receitas externas provenientes dos saldos correntes no balanço de pagamentos permitiram o acúmulo de reservas e o desendividamento externo líquido do setor público. Por outro lado, os déficits nominais contribuíram para o aumento da dívida interna líquida, através do processo anteriormente mencionado. Por fim, o processo de acumulação de reservas se mostrou mais intenso do que o de aumento do endividamento interno do setor público, engendrando a redução da dívida líquida total do Estado.

\footnotetext{
12 Segundo Hicks (1967), os ativos podem ser classificados como de transação, de reserva ou de investimento. Ativos de transação são todos os que podem ser utilizados na compra e venda de bens e outros ativos. A moeda e os depósitos bancários cumpririam esta função. Ativos de reserva são todos os ativos que são mantidos no portfólio de um determinado agente porque estes representam boas reservas de valor. Ativos de investimento são preferidos por determinados agentes porque oferecem um retorno pecuniário ou a possibilidade de valorização de seu preço. As classificações entre ativos de reserva e ativos de investimento não seriam fixas, dependeriam das estratégias de atuação de cada agente e dos mercados nos quais eles podem ou não atuar.

13 Dos Santos \& Macedo e Silva (2010) destacam a interação destes balanços para a economia dos EUA, evidenciando como o ciclo de crescimento desta foi alcançado pelos saldos negativos das famílias e empresas norte-americanas, caracterizando um processo de endividamento persistente. No mesmo período, o setor financeiro foi amplamente superavitário, recebendo os ganhos do referido processo de endividamento. Os ganhos financeiros foram ampliados pelo recorrente déficit público.
} 


\section{A POLÍTICA MACROECONÔMICA DOS ANOS 2000}

O atual regime de políticas econômicas consiste essencialmente na busca de superávits primário por parte da política fiscal, estabelecimento de metas de inflação a serem atingidas pelo controle da taxa de juros de curto prazo pela via monetária e taxa de câmbio flutuante pela política cambial. Não é possível compreender este atual conjunto de políticas econômicas sem antes delinear alguns aspectos da estabilização inflacionária brasileira.

De forma sintética, o plano de estabilização inflacionária consistia em ancorar os preços domésticos aos preços externos através de relativa estabilidade cambial ${ }^{14}$. Não faz parte do objetivo deste artigo discutir os pormenores da concepção e execução do plano de estabilização. Entretanto, vale ressaltar que, como menciona Franco (1993), a adoção de um plano de estabilização nos moldes do que fora executado dependia dos seguintes fatores: contração fiscal para não ocorrer deterioração das expectativas inflacionárias ${ }^{15}$; quantidade elevada de reservas em moeda estrangeira na qual ocorresse ancoragem para a sustentação da mesma; e controle sobre a expansão dos agregados monetários para que o aumento do crédito não gerasse excesso de demanda e para que não ocorresse uma liquidação massiva de ativos domésticos e aquisição de ativos externos.

O próprio autor sinaliza que as soluções destes problemas potenciais seriam o ajuste fiscal com redução de gastos e (ou) aumento de tributos e a elevação das taxas de juros dos ativos domésticos (essencialmente dívida pública). A contração fiscal impediria a atuação da autoridade pública como um fator de expansão da quantidade de moeda para agentes privados. A elevação das taxas de juros doméstica atuaria na atração de capitais externos e constituição de reservas para a manutenção da âncora cambial e inibiria a expansão do crédito e a fuga de capitais para ativos externos que representavam boas reservas de valor. Nota-se que, com exceção da política cambial, os moldes da política econômica atual foram traçados no plano de estabilização.

Como sinalizado anteriormente, ao longo da década de 1990, os elevados déficits em transações correntes corroeram as reservas internacionais e a contração de liquidez internacional, devido às crises em países emergentes no fim da década de 1990, dificultaram a entrada de capitais no país mesmo com taxas de juros elevadas; decretando o fim da ancoragem cambial. Assim, instituiu-se o regime de câmbio flutuante, por parte da política cambial, e o regime de metas de inflação pela via monetária.

No entanto, a ancoragem dos preços domésticos não estaria associada ao hiato de produto, como sugerido na proposição original de Taylor $(1993)^{16}$,

\footnotetext{
${ }^{14}$ Era permitida a flutuação da taxa de câmbio em um sistema de bandas assimétricas, determinando um nível máximo para a taxa de câmbio de reais por dólares. Se a taxa de câmbio ameaçasse ultrapassar seu valor de teto, a autoridade monetária atuaria para manter a estabilidade cambial e, por consequência, dos preços.

${ }^{15}$ A expansão dos déficits públicos implicaria na expansão dos agregados monetários, frente a isso os agentes poderiam projetar expectativas de inflação mais elevadas, antecipando aumento de preços esperados para períodos correntes.

16 Taylor (1993) sugere uma equação de reação da taxa de juros baseada na diferença entre o produto corrente e o produto potencial. Desta forma, uma economia sobreaquecida, com produto corrente acima do potencial ou natural e vivenciando um processo de elevação de preços, teria sua taxa de juros básica
} 
mas pela taxa de câmbio, mantendo, essencialmente, todo o arcabouço precedente ${ }^{17}$. A elevada taxa de juros continuaria atuando como fonte de atração de capitais estrangeiros, restrição do mercado de crédito e inibição de liquidação de ativos domésticos e fuga para ativos externos, com o intuito de manter os preços domésticos ancorados nos preços externos pela relativa estabilidade cambial. O regime ganhou um novo nome - "metas de inflação" mas está constituído sobre a mesma ótica do plano de estabilização.

É difícil supor que a simples modificação do nome do regime modifique a maneira como os agentes privados traçam suas expectativas inflacionárias e como constituem seus contratos, principalmente quando os instrumentos são essencialmente os mesmos: taxa de juros elevada e contração fiscal na tentativa de manter estável a taxa de câmbio e o nível de preços.

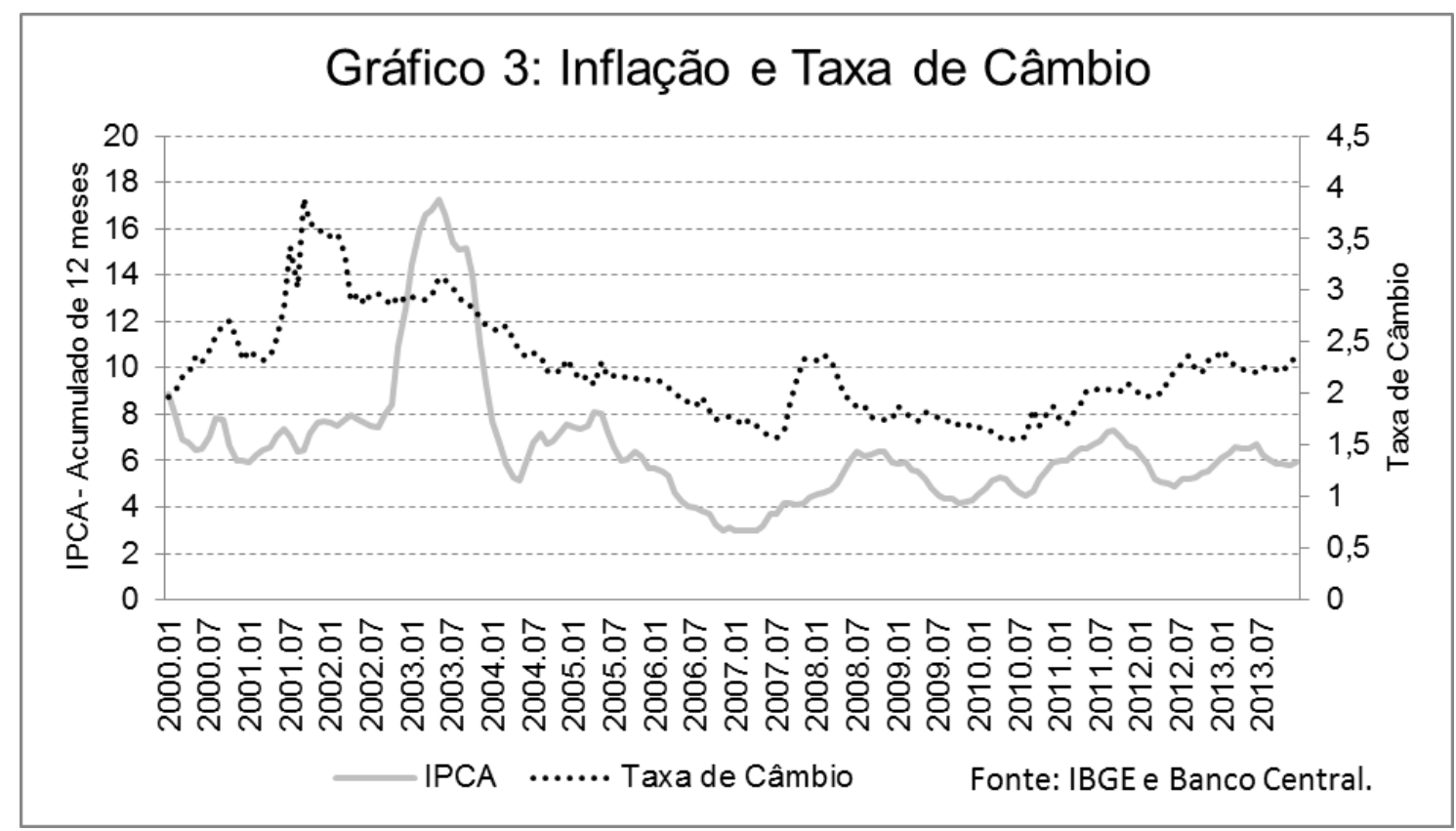

Fonte: IBGE e Banco Central

O Gráfico 3 demonstra a reação da inflação (IPCA - Índice Nacional de Preços ao Consumidor Amplo) após variações da taxa de câmbio. Alguns meses após o choque cambial de 2001 e 2002 a inflação se eleva acima de $16 \%$. A tendência de queda da taxa de câmbio, iniciada em 2003, é acompanhada, alguns meses depois, por uma tendência de queda do índice de inflação. Após novo choque cambial em 2008, a inflação se eleva novamente e se estabiliza em torno dos $6 \%$ enquanto a taxa de câmbio evidencia uma leve tendência de alta.

O Banco Central do Brasil (2012) evidencia que os efeitos de variação da taxa de câmbio, como potencial acelerador de preços, são muito mais intensos do que os efeitos de elevação da taxa de juros e geração de superávits primários como efeitos depressivos de preços. O mesmo trabalho

elevada com o intuito de reduzir o produto corrente e, consequentemente, o nível de preços. Seguindo este modelo, os preços domésticos estariam ancorados ao hiato de produto.

17 A equação de reação da taxa de juros utilizada pelo Banco Central do Brasil incorpora tanto o hiato de produto quanto a variação da taxa de câmbio, mas como o próprio Relatório de Inflação do Banco Central do Brasil (2012) demonstra, os efeitos dos choques cambiais provocam efeitos mais intensos. 
também ressalta que os efeitos da variação do câmbio são mais intensos sobre os preços dos alimentos e bebidas do que outros bens e serviços.

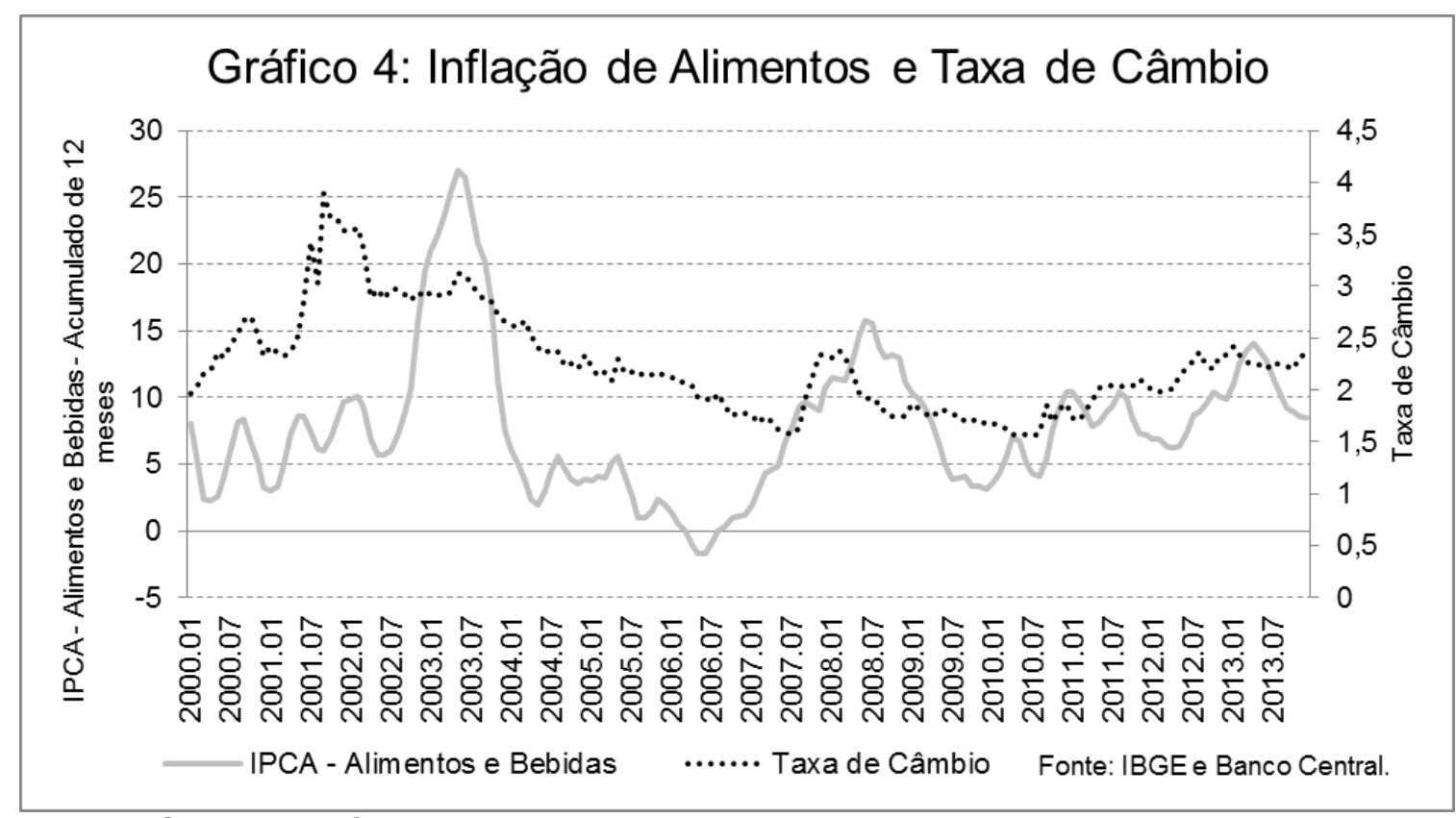

Fonte: IBGE e Banco Central

O Gráfico 4 ilustra este movimento. O choque cambial de 2001 e 2002 acelerou os preços dos alimentos, alguns meses depois, para além dos $25 \%$. A tendência de queda da taxa de câmbio, iniciada em 2003, também mostrou forte impacto sobre o setor que teve deflação em 2006. No entanto, após esta data, os preços dos alimentos se aceleraram antes mesmo de um impacto cambial, fruto do aumento de preços nos mercados internacionais (Gráfico 2). O comportamento do setor de alimentos é assim caracterizado devido à possibilidade de exportar tais bens para outras economias. As elevações na taxa de câmbio, ou aumento dos preços nos mercados externos, tornam a exportação destes bens altamente vantajosa, restringindo a oferta interna e elevando os preços domésticos.

Alves \& Correa (2013), na tentativa de adaptar a curva de Phillips novokeynesiana às especificidades recentes da economia brasileira, dividem a economia em dois setores: bens comercializáveis e bens não comercializáveis. Para os bens comercializáveis, as variações de preços estariam relacionadas ao hiato de capacidade produtiva instalada, diferença entre a capacidade de efetivamente instalada e a taxa de capacidade produtiva instalada não aceleradora da inflação. Para os bens não comercializáveis, adota-se a relação convencional novo-keynesiana de hiato de desemprego, diferença entre o desemprego observado e a taxa de desemprego não aceleradora da inflação. $\mathrm{O}$ hiato de produto, diferença entre produto corrente e produto natural, influenciaria os preços de forma geral. Os hiatos de capacidade instalada e produto contribuem positivamente para inflação e o hiato de desemprego contribui negativamente ${ }^{18}$.

\footnotetext{
${ }^{18}$ Os autores destacam a dificuldade e possível imprecisão das estimativas das taxas de desemprego e de ocupação da capacidade produtiva não aceleradoras da inflação e do produto potencial.
} 
A conclusão dos autores indica que o aquecimento do mercado de trabalho ao longo da década marcado pela redução do desemprego teve um impacto significativo nos preços dos bens não comercializáveis. Para os bens comercializáveis, a trajetória mais recente indicaria um movimento contrário devido ao desaquecimento da economia brasileira. Os autores consideraram que o setor de bens comercializáveis é principalmente price-taker, logo a influência interna nos preços destes bens se daria pelo excesso de capacidade de utilização, ou uma inflação de custos.

É importante observar que os efeitos da taxa de juros sobre as variáveis não são levados em consideração, logo, não é possível avaliar se o modelo convencional de controle inflacionário pela taxa de juros é factível. Desta forma, para o período recente, novas elevações na taxa de juros poderiam deprimir ainda mais a atividade industrial e o crescimento sem obter os resultados esperados sobre a taxa de desemprego e o mercado de trabalho.

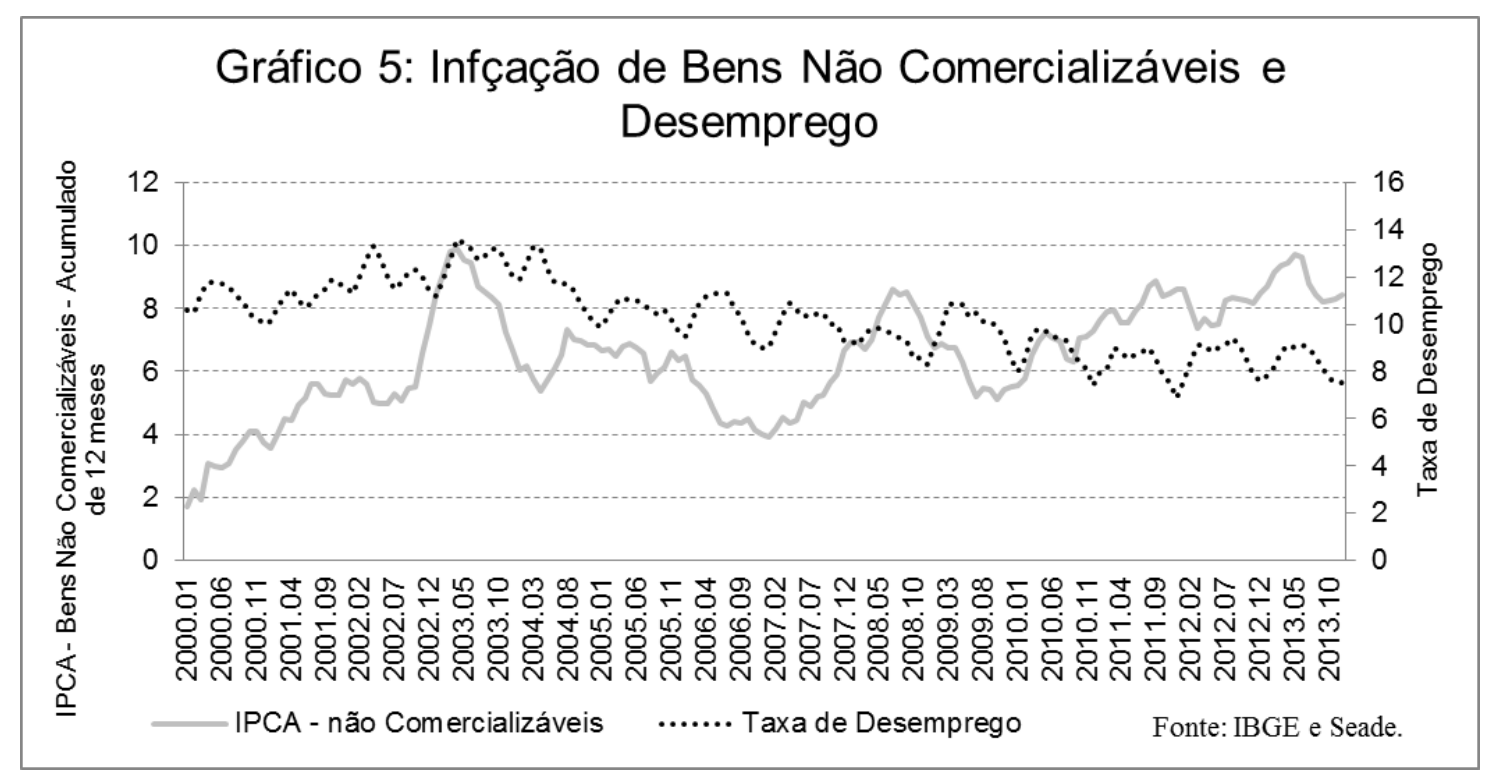

Fonte: IBGE e Seade

O movimento mencionado por Alves \& Correa (2013) pode ser observado pelo Gráfico 5. Ao longo da década a redução do nível de desemprego foi acompanhada pelo aumento de preços dos bens comercializáveis. Nota-se que os efeitos cambiais de 2001 e 2002 também são preponderantes sobre a inflação dos referidos bens, uma vez que a indexação de contratos privados, reminiscência da década de 1980, ainda permanece como uma prática comum. Como mencionam Coutinho \& Belluzzo (1998), a inflação de bens não comercializáveis já era uma característica comum nos países desenvolvidos ao longo dos ciclos de expansão das décadas de 1990 e 2000.

Para Keynes (1936), os processos de expansão de preços são fruto da incapacidade da oferta de determinados bens e serviços reagir aos aumentos de preços precedentes. O setor produtor de alimentos demora a ampliar a oferta de seus produtos, uma vez que cada um deles obedece a um ciclo produtivo natural, mais ou menos extenso. $O$ setor de bens não comercializáveis, notadamente serviços (Gráfico 6), marcado pela sua incapacidade de gerar ganhos de produtividade, só pode ampliar sua oferta 
através do emprego de mais indivíduos; com um mercado de trabalho com baixo desemprego a oferta de serviços reage cada vez mais lentamente ao aumento de preços.

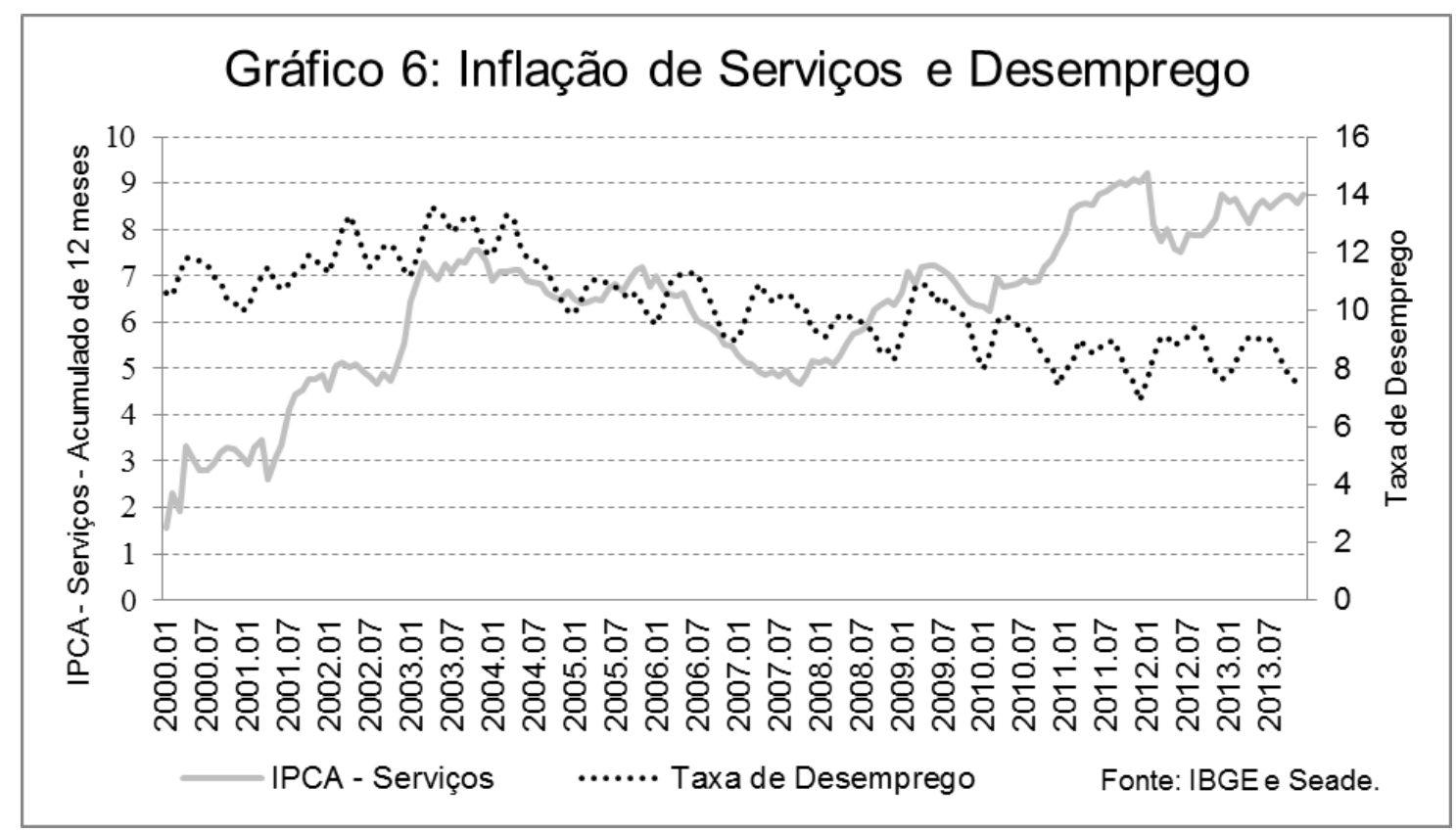

Fonte: IBGE e Seade

As características da inflação brasileira demonstraram a dificuldade da atual combinação de políticas macroeconômicas em atingir seu objetivo. A geração de superávits primários teria o intuito de reduzir o poder de gasto de agentes privados, reduzindo, assim, os gastos das famílias brasileiras com os serviços; e as elevadas taxas de juros deveriam atrair capitais, reduzir a taxa de câmbio e controlar a inflação de alimentos pelo desestímulo à oferta externa.

No entanto, os efeitos de redução de gastos são abrangentes e não equânimes. Não há justificativa para que a redução de gastos públicos reduza os gastos privados com serviços de forma mais acentuada do que o gasto privado com outros bens. No atual cenário, uma redução de gastos privados com bens industriais pode deprimir ainda mais as expectativas de retorno do setor empresarial, reduzindo o investimento corrente.

As elevadas taxas de juros têm seu efeito limitado no controle de preços, apesar do impacto severo na determinação do nível de investimento. Em um contexto de moeda inconversível, como salientado por Carneiro (2003 e 2008), a incapacidade da moeda doméstica em ser aceita no plano externo como reserva de valor (tanto para residentes quanto para não residentes) implica em elevada volatilidade cambial, uma vez que a moeda doméstica e os ativos referenciados na mesma sofrem das variações na percepção do risco de iliquidez a eles associados por parte dos agentes globais ${ }^{19}$.

19 Kaldor (1960) modifica os fatores que compõem as taxas próprias de juros desenvolvidas por Keynes (1936). As taxas próprias de juros delineiam uma teoria de escolha de ativos e são determinadas por quatro fatores: a expectativa de valorização ou desvalorização em termos monetários, os retornos pecuniários associados à posse de um determinado ativo, o custo de manter esse ativo no portfólio do agente e a capacidade deste ativo ser rapidamente transformado em moeda. $O$ risco de iliquidez 
Nas fases de expansão dos ciclos de liquidez global, a percepção do risco de iliquidez dos agentes globais para com os ativos domésticos se reduz, facilitando a entrada de capitais e permitindo a redução da taxa de juros; movimento que pode ser reforçado pela queda das taxas de juros nos mercados de moedas conversíveis. Na reversão destes ciclos, a percepção de risco de iliquidez se eleva, forçando a elevação da taxa de juros como efeito compensatório na tentativa de evitar uma fuga massiva de capitais. No entanto, a reação na taxa de juros não é imediata e novos aumentos desta podem ser seguidos de subsequentes elevações no risco de iliquidez, o que exacerba a volatilidade da taxa de câmbio e, por consequência, dos preços dos bens e serviços internos.

Portanto, frente à volatilidade cambial, o Banco Central do Brasil acaba por ser obrigado a intervir no mercado futuro de câmbio na tentativa de diminuir as oscilações cambiais. Mesmo sob um regime de câmbio flutuante, as intervenções se fazem necessárias para diminuir o impacto nos preços e no setor produtivo. Da mesma forma que uma desvalorização drástica da moeda nacional gera aumento dos preços internos, uma valorização acentuada inibe a atividade industrial doméstica, uma vez que este processo desvaloriza artificialmente as importações, tornando-as mais atrativas do que os mesmos produtos fabricados internamente.

\section{CONSIDERAÇÕES FINAIS}

O ciclo de expansão e retração (ou estagnação) da Economia Brasileira recente está intimamente relacionado ao ciclo de expansão e retração externo. Ao longo da década de 2000, a expansão da economia brasileira foi financiada pela capitação de poupanças externas, representada pelos saldos em transações correntes positivos. Este processo foi possível devido à expansão de liquidez nos mercados internacionais, que elevou os preços das commodities, como ressalta Wray (2008), e a expansão da economia chinesa e outros mercados emergentes demandantes destes produtos.

Os saldos em transações correntes reduziram a dependência de elevadas taxas de juros para atrair capitais externos e manter os preços estáveis ou declinantes através da valorização da moeda doméstica; criando espaço para a redução da taxa de juros interna. A queda desta, aliada a política ativa do BNDES, como ressaltado por Dedecca, Trovão \& Souza (2014), foi responsável pela ampliação do investimento agregado, o que deu início a fase de expansão vigorosa do produto interno. O aumento da absorção interna, aliado aos saldos externos, elevou a arrecadação pública, o que

evidenciaria a dificuldade do ativo em ser transformado em moeda. Desta forma, em equilíbrio, os ganhos oriundos da expectativa de valorização ou dos retornos pecuniários seriam compensados pelo risco de iliquidez. Em momentos de otimismo, as expectativas de valorização ou de retorno pecuniário seriam percebidas como superiores ao risco de iliquidez, contribuindo para a expansão do mercado deste ativo. Em momento de pessimismo, a percepção de risco de iliquidez se sobrepõe às expectativas de ganho e os agentes procuram os ativos com os menores riscos ou a própria moeda, que apresentaria risco nulo. Para o cenário internacional, apenas as moedas conversíveis poderiam apresentar risco de iliquidez nulo ou negligenciável, as demais estariam sujeitas as alterações na percepção do mesmo. 
permitiu a expansão das políticas públicas de distribuição de renda, como sublinham os autores acima mencionados.

A expansão da renda interna, somada à ampliação do mercado consumidor, resultado das políticas públicas de distribuição de renda, e a valorização da moeda doméstica, possibilitada pelos saldos externos e atuação branda do Banco Central do Brasil nos mercados de câmbio, acabou por ampliar as importações, reduzindo progressivamente os referidos saldos. Assim, a economia brasileira foi, no decorrer do ciclo, retomando sua vulnerabilidade frente aos eventuais choques de liquidez externos.

Em 2008, após o pânico financeiro ser instaurado pela falência do Lehman Brothers, o enxugamento da liquidez global devido à deflação das dívidas hipotecárias securitizadas, como salientou Freitas \& Cintra (2008), engendrou em elevadas saídas de capitais do país, desvalorizando significativamente a moeda nacional. Os baixos saldos externos, em um cenário de contração da liquidez internacional, aumentaram a percepção de risco de iliquidez dos agentes externos e internos quanto aos ativos nacionais e a moeda na qual estão lastreados, forçando a elevação da taxa de juros interna. Nos anos posteriores, este efeito foi compensado pela significativa redução das taxas de juros nas economias de moeda conversível.

Entretanto, os seguidos déficits em transações correntes, que contribuíram para a queda das poupanças públicas e privadas, e a forte redução da demanda internacional, tornaram a economia brasileira novamente dependente da taxa de juros para atrair capitais e manter relativamente estável a taxa de câmbio e o nível de preços. Logo, frente a novos choques de liquidez, e aumento da percepção de risco de iliquidez, o atual arcabouço de políticas macroeconômicas poderá apenas elevar a taxa de juros na tentativa de conter o aumento da taxa de câmbio e dos preços internos.

Segundo Carneiro (2008), as vertentes ortodoxas das teorias relacionadas à tese de inconversibilidade monetária afirmam que a redução da dependência das poupanças externas para moedas inconversíveis poderia ser atingida através da obtenção da estabilidade de preços. O autor afirma que isto pode ser contestado, uma vez que a estabilidade de preços foi alcançada em muitos países de moeda inconversível, mas esta condição ainda é presente nestas economias. Na verdade, a estabilidade de preços foi alcançada com a utilização das poupanças externas.

Em seus modelos usuais de crescimento com restrição de balanço de pagamentos, McCombie \& Thirlwall (1994) sinalizam que economias dependentes de financiamento externo se tornam estagnadas quando este se reduz, em especial, quando o processo de industrialização não resultou em modificação do diferencial de elasticidades de exportação e importação ${ }^{20}$. A economia brasileira recente desenvolveu um círculo vicioso semelhante: a

\footnotetext{
20 McCombie \& Thirlwall (1994) afirmam que o processo de industrialização resulta na modificação dos bens exportados e bens importados, o que altera as elasticidades preço e renda da demanda dos mesmos. Ao modificar a base produtiva, uma determinada economia passará a depender menos da importação de bens com elevadas elasticidades renda e preço e passará a exportar mais destes mesmos bens, criando a possibilidade de intensificar ou ampliar o ciclo de crescimento devido aos ganhos oriundos das demandas externas. Economias que não conseguem expandir ou concluir o processo de industrialização estariam fadadas a ciclos curtos de crescimento interrompidos pelas restrições de balanço de pagamentos oriundas da elevação das importações devido ao aumento da renda interna ou interrupção do financiamento externo.
} 
interrupção do acúmulo de poupanças externas força a autoridade monetária a elevar as taxas de juros domésticas na tentativa de manter os preços estáveis e acaba por condenar o crescimento, inviabilizando a realização de novos investimentos e as possibilidades de surgimento de mecanismos privados de financiamento interno.

Portanto, este artigo procurou salientar de maneira sucinta a relação entre o movimento cíclico da economia brasileira recente e seus corolários no atual marco de políticas macroeconômicas. A expansão dos mercados externos permitiu a expansão monetária e creditícia interna, elevando investimento e renda. A vulnerabilidade através de inflexões no balanço de pagamentos permaneceu latente ao longo do período, tornando-se evidente após a contração de liquidez nos mercados externos, o que impediu a continuidade das expansões monetárias e creditícias.

\section{REFERÊNCIAS BIBLIOGRÁFICAS}

ALVES, S. \& CORREA, A. Um Conto de Três Hiatos: Desemprego, Utilização da Capacidade Instalada da Indústria e Produto. Banco Central do Brasil: Trabalho para Discussão 339, dezembro, 2013.

BACHA, E. O Fisco e a Inflação: uma Interpretação do caso Brasileiro. Revista de Economia Política, vol. 14, 1994.

BANCO CENTRAL DO BRASIL. Relatório de Inflação, junho, 2012.

CARNEIRO, R. A política macroeconômica da era FHC ao governo Lula: da trindade impossível à autonomia necessária. VELLOSO, João Paulo dos Reis (Coor.) Governo Lula: novas prioridades, 2003.

CARNEIRO, R. "Globalização e inconversibilidade monetária". Revista de Economia Política 28 (4), pp. 539-556, outubro-dezembro 2008.

COUTINHO, L. \& BELLUZZO, L. G. M. "Financeirização" da riqueza, inflação de ativos e decisões de gasto em economias abertas. Economia e Sociedade, Campinas, (11): 137-50, dez. 1998.

DEDECCA, C. TROVÃO, C. \& SOUZA, L. Desenvolvimento e Equidade: Desafios do Crescimento Brasileiro. Novos Estudos (98), março, 2014.

DEMBIERMONT, C. DREHMANN, M. \& MUKSAKUNRATANA, S. How much does the rivate sector really borrow? A new database for total credit to the private non-financial sector. BIS Quarterly Review, Março, 2013.

DOS SANTOS, C. \% MACEDO E SILVA, A. Revisiting "New Cambridge": The Three Financial Balances in a General Stock-flow Consistent Applied Modeling Strategy. The Levy Economics Institute of Bard College: Working Paper No. 594, maio, 2010.

EICHENGREEN, B. Globalizing capital: a history of the international monetary system. Princeton: Princeton University Press, 1996.

FARHI, M. O impacto dos ciclos de liquidez no Brasil: mercados financeiros, taxa de câmbio, preços e política monetária. Em Carneiro, $R$ 
(org) A supremacia dos mercados e a política econômica do Governo Lula. SP: UNESP, 2006.

FISHER, S. \& BLANCHARD, O. Lectures on Macroeconomics. Cambridge: MIT Press, 1989.

FLEMING, J. M. Domestic Financial Policies under Fixed and under Floating Exchange Rates. Staff Papers - IMF, Vol. 9, No. 3. Novembro, 1962.

FRANCO, G. Alternativas de Estabilização: gradualismo, dolarização e populismo. Revista de Economia Política, vol. 13, no 2 (50), abril-junho, 1993.

FREITAS, M. \& CINTRA. M. Inflação e deflação de ativos a partir do mercado imobiliário americano. Revista de Economia Política, vol. 28, ํㅡ 3 (111), pp. 414-433, julho-setembro, 2008.

INTERNACIONAL MONETARY FUND. World Economic Outlook, outubro, 2014.

GODLEY, W. Seven Unsustainable Processes: Medium-Term Prospects and Policies for the United States and the World. Special Report. Annandale-on-Hudson, N.Y.: Levy

Economics Institute of Bard College, 1999.

HICKS, J. Critical Essays in Monetary Theory. Lectures I-III. Oxford, Clarendon Press, 1967.

KALDOR, N. Essays on Economic Stability and Growth. Capítulos 1 e 2. Illinois, The Free Press of Glencoe, 1960.

KALECKI, M. Teoria da Dinâmica Econômica. São Paulo, Editora Nova Cultural, 1977.

KEYNES, J. M. (1930). A Treatise on Money: The Pure Theory of Money. The Collected Writings of John Maynard Keynes, v. 5. Cambridge, MacMillan, 1971.

KEYNES, J. M. (1936). A Teoria Geral do Emprego, do Juro e da Moeda. São Paulo, Editora Nova Cultural, 1996.

LERNER, A. Functional Finance and the Federal Debt. Social Research, 10(1), pp. 38-51, 1943.

LOPREATO, F. Política fiscal: mudanças e perspectivas. In: Carneiro, $R$ (org) A supremacia dos mercados e a política econômica do Governo Lula. SP: UNESP, 2006.

MCCOMBIE, J. \& THIRLWALL, A. Economic Growth and the Balance-ofPayments Constraint. London: Macmillan, 1994.

MINSKY, H. (1975). John Maynard Keynes. McGraw-Hill, Nova lorque, 2008.

MODENESI, A. M. Regimes Monetários: teoria e a experiência do Real. Ed. Monole, 2005.

MUNDELL, R. A. Capital Mobility and Stabilization Policy under Fixed and Flexible Exchange Rates. The Canadian Journal of Economics and Political Science, Vol. 29, No. 4. Novembro, 1963. 
OBSTFELD, M. SHAMBAUGH, J. \& TAYLOR, A. The Trilemma in History: Tradeoffs among Exchange Rares, Monetary Policies, and Capital Mobility. NBER Working Paper Series: março, 2004.

ROCCA, C. \& SANTOS JR, L. Redução da Taxa de Poupança e Financiamento dos Investimentos no Brasil - 2010 a 2013. Centro de Estudos de Mercado de Capitais, IBMEC, novembro, 2014.

SERRANO, F. Do ouro imóvel ao dólar flexível. Economia e Sociedade, Campinas, v. 11, n. 2 (19), p. 237-253, jul./dez. 2002.

SOUZA, L. A Crise Financeira de 2008: Uma Interpretação Teórica Heterodoxa. Dissertação de Mestrado, Campinas, 2012.

STEINDL, J. Maturidade e estagnação no capitalismo americano. São Paulo: Nova Cultural, 1983.

STIGLITZ, J. \& GREENWALD, B. Rumo a um Novo Paradigma em Economia Monetária. São Paulo: Francis, 2004.

TAYLOR, J. B. Discretion versus Policy Rules in Practice. CarnegieRochester Conference Series on Public Policy, vol. 39, 1993.

TRIFFIN, R. Gold and the Dollar Crisis. New Haven, Conn.: Yale University Press, 1960.

WRAY, L. R. The Commodities Market Bubble: Money Manager Capitalism and the Financialization of Commodities. Public Policy Brief, The Levy Economics Institute of Bard College, 2008. 